\title{
Redescriptions of Two Closely Resembling Linnaemya Species (Insecta: Diptera: Tachinidae) New to Korea
}

\author{
Jong-Su Lim and Ho-Yeon Han* \\ Division of Biological Science and Technology, Yonsei University, Wonju-si, \\ Gangwon-do 220-710, Korea
}

\begin{abstract}
In the process of revising the tachinid genus Linnaemya Robineau-Desvoidy in Korea, we have discovered two species for the first time in Korea. They closely resemble each other and need to be identified with caution. We here provide detailed redescriptions and illustrations with their diagnostic characters indicated. Linnaemya atriventris can be distinguished from L. hirtipennis by the combination of the following characteristics: 1) abdomen black in ground color; 2) wing vein R1 without setulose; 3) hypandrium without secondary posterior lobe; 4) male with antero-basal 1/3 of flagellomere 1 distinctly swollen; and 5) postgonite very weakly curved dorsally.
\end{abstract}

Key words: Taxonomy, Diptera, Tachinidae, Linnaemyiini, Linnaemya, Korea

\section{INTRODUCTION}

Linnaemya Robineau-Desvoidy is one of the largest genera of the subfamily Tachininae with worldwide distribution including 125 nominal species (Crosskey, 1980; Herting, 1984; Shima, 1986). This genus can be distinguished from all other genera of Linnaemyiini by the combination of the following characteristics (Crosskey, 1973, 1976): 1) parafacial bare with normally three sternopleural setae, $1+3$ intraalar setae; 2) epistome prominent but not strikingly nasute; 3) vibrissa inserted above the level of the epistomal margin by a distance less than the length of the second antennal segment; and 4) prosternal membrane and prosternum bare.

Shima (1986) studied Oriental and Japanese fauna and recorded 41 species including 17 Japanese species. In Korea, however, L. microchaetopsis is the only species known up until now (Shima, 1986). In the process of revising Korean Linnaemyiini (Lim and Han, in prep.), we have discovered a number of specimens of $L$. atriventris and L. hirtipennis new to Korea. They closely resemble each other and need to be identified with caution. We provide herein detailed redescriptions and illustrations of these species.

\section{MATERIALS AND METHODS}

The terminology and morphological interpretations used in this paper follow Crosskey (1973), McAlpine (1981) and

*To whom correspondence should be addressed

Tel: 82-33-760-2254, Fax: 82-33-763-4323

E-mail: hyhan@yonsei.ac.kr
Wood (1987), but those of male terminalia follow Shima (1986). In addition, we used the following ten ratios (modified from Han and Norrbom, 2005): vertex-head ratio (vertex width/head width); eye ratio (shortest eye diameter/ longest eye diameter); frons-head ratio (narrowest width of frons in dorsal view/width of head); gena-eye ratio (genal height/longest eye diameter)-genal height is the distance between the ventral eye margin and the ventral genal margin anterior to the genal seta; gena-parafacial ratio (genal height/parafacial width); flagellomere1-pedicel ratio (length of flagellomere $1 /$ length of pedicel); vein $\mathrm{R}_{4+5}$ ratio (distance along vein $R_{4+5}$ between crossvein $R-M$ and vein $R_{4+5}$ apex/distance between crossvein R-M and basal node of vein $R_{4+5}$ ); vein $M$ ratio (distance along vein $M$ between crossveins R-M and DM-Cu/distance between crossveins R$\mathrm{M}$ and $\mathrm{BM}-\mathrm{Cu}$ ); subcosta-costa ratio (length of pterostigma/length of costal cell, both measured along vein $\mathrm{C}$ ); wing-thorax ratio (wing length/thorax length).

All the Korean specimens examined in this study are deposited in the Division of Biological Science and Technology, Yonsei University, Wonju-si, Korea (YSUW). Abbreviations of the other institutions mentioned in the text are as follows: Biological Laboratory, College of General Education, Kyushu University, Fukuoka, Japan (BLKU); The Natural History Museum, Department of Entomology, Cromwell Road, London SW7 5BD, England, UK (BMNH); United States National Museum of Natural History, United States National Entomological Collection, Washington, DC 20560, USA (USNM); Zoological Museum, Academy of Sciences, Russian Academy of Sciences, Universitetskaya, Naberzhnayal B-164, St. Petersburg, Russia (ZISP). 


\section{TAXONOMIC ACCOUNTS}

Order Diptera Linnaeus, 1758

Familly Tachinidae Robineau-Desvoidy, 1830

Genus Linnaemya Robineau-Desvoidy, 1830

${ }^{1} *$ Linnaemya atriventris (Malloch) (Figs. 1, 3A-C)

Palpina atriventris Malloch, 1935: 580 (type-locality: Cameron Highland, Pahang, Malaya; Holotype ð7, BMNH).

Linnaemyia (sic) montshadskyi Zimin, 1954: 272 (type-locality: Russia, Primorskiy, Kamenushka nr Shkotovskii region; Holotype $\sigma^{7}$, ZISP).

Linnaemya montshadskyi: Herting and Dely-Draskovits, 1993: 289 (in Palaearctic catalog).

Linnaemya montschadskyi: Incorrect subsequent spellings of montshadskyi.

Material examined. JAPAN: Oudaba, Kuroson, Tosa, Hatagun, 17-VII-1953 (S.H. Samatsu), 1 જ (USNM; identified as L. montshadskyi by L.P. Mesnil, 1962). KOREA: [CHUNGCHEONGBUK-DO] Chungju-si, Jongmin-dong, Recreational Forest to Mt. Gyemyeongsan peak, 30-VII-2003 (D.-S. Choi \& H.-W. Byun), 1 이1우; [GANGWON-DO] Pyeongchang-gun, Jinbu-myeon, Pangadari, Mt. Odaesan, 31-VII1984 (H.-Y. Han \& K.-E. Ro), 3 ठ ๙ ; ditto, 12-VIII-1984, 1 우; ditto, 7-IX-1985, 17 지 저2우 우; ditto, Bukdaesa to sangwangbong, 12-IX-2005 (D.-S. Choi et al.), 1 우; ditto, 17-VI-2006 (D.-S. Choi \& H.-W. Byun), 1 우; Wonju-si, Heungeop-myeon, Maeji-ri, Yonsei Univ. Campus, 29-VII1996 (H.-W. Byun), 1 ð ; ditto, 22-IX-1996 (H.-Y. Han \& H.-W. Byun), 1 우; ditto, Saje-ri, 13-X-1996 (S.-H. Nam), 1 우; ditto, 24-VII-1997 (H.-W. Byun \& D.-S. Choi), $1 \sigma^{7}$; ditto, 17-IX-2002 (H.-W. Byun), 1 ठ ; ditto, 4-X-2002 (H.W. Byun \& D.-S. Choi), 1 우; ditto, 28-VI-2003 (H.-W. Byun), 1 우; ditto, Hoechon-ri, 4-VII-2003 (O.-Y. Lim \& H.-S. Lee), 1 우; ditto, 16-VII-2003 (H.-W. Byun), 1 우; ditto, 26-VII-2003 (H.-W. Byun \& H.-S. Lee), 1 우; ditto, 4IX-2003 (D.-S. Choi \& H.-S. Lee), 1 우; ditto, 14-IX-2003 (D.-S. Choi \& H.-W. Byun \& H.-S. Lee), $2 \sigma^{7} \sigma^{\text {乃 }}$; ditto, 21IX-2003 (H.-W. Byun), 1 우; ditto, 1-XI-2003 (D.-S. Choi \& H.-W. Byun \& H.-S. Lee), $1 \sigma^{\top}$; ditto, 5-VII-2004 (D.-S. Choi \& H.-W. Byun \& J.-S. Soh), 2 우 우; ditto, 18-VII2004 (H.-W. Byun), 1 ठ $^{7}$; ditto, 20-IX-2005 (H.-W. Byun), 1 శౌ ; ditto, 4-X-2005 (H.-W. Byun), 1 우; ditto, 15-VI-2006 (J.-S. Lim), 3 ठ ఠ ; ditto, 19-VII-2006 (S.-M.-R. Hwang), 2

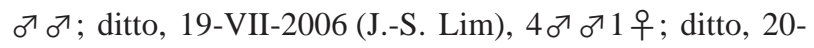
VII-2006 (S.-M.-R. Hwang), 1 우; ditto, 31-VII-2006 (D.-J. Cha), 1 우; Wonju-si, Panbu-myeon, Seogok-ri, Mt. Baekunsan, from Yongsu-gol to 1,087 m peak, 18-IX-2000 (D.-S.
Choi \& S.-K. Kim \& C.-H. Park), 1 ð ; ditto, 12-VIII-2002 (K.-D. Han \& J.-D. Yeo), $1 \sigma^{\top}$; ditto, 18-VIII-2002 (H.-W. Byun et al.), $1 \sigma^{\nearrow}$; ditto, 14-VI-2005 (H.-Y. Han et al.), 1 ð ; ditto, 20-VII-2005 (H.-S. Lee \& S.-M.-R. Hwang), 1 ठ ; ditto, 3-VIII-2007 (S.-W. Suk), 1 ठ ; Hongcheon-gun, Naemyeon, Bangnae-ri Mt. Maenghyeonsan, 15-X-2003 (H.-W. Byun \& H.-S. Lee), $1 \sigma^{7}$; ditto, North. Valley of Mt. Gyebangsan, 20-VIII-2007 (H.-S. Lee \& J.-M. Jung), 1 우; Jeongseon-gun, Nam-myeon, Mt. Mindungsan from Yupyeong-ri to 1,119 m peak, 25-IX-2003 (H.-Y. Han et al.), 1 o $^{7} 2$ 우 우; ditto, 29-VIII-2005 (H.-Y. Han et al.), 1 우; Samcheok-gun, Dogye-eup, Gwangmyeongsa to Sangdeok-ri, 10-X-2003 (D.-S. Choi \& H.-W. Byun \& H.-S. Lee), 1 우; Yeongwolgun, Seo-Myeon, Ssangyong-ri, 5-VIII-2003 (O.-Y. Lim \& H.-S. Lee), 1 우; [GYEONGGI-DO] Mt. Cheonggyesan, 1VII-1984 (H.-Y. Han \& K.-E. Ro), 1 శ ㅈ Geumgok-ri, 31VII-1984 (H.-Y. Han), 1 ð ; Mt. Chungnyeongsan, 6-VI-1985 (H.-Y. Han \& K.-E. Ro), 1 б ; Yangju-si, Goam-dong, 2VIII-2006 (D.-S. Choi et al.), 1 우. All the above Korean specimens are deposited in YSUW.

Diagnosis. This species can be readily distinguished from other Linnaemya species by the following combination of characteristics; 1) single pair of lateral scutellar seta; 2) pedicel without wart-like process; 3) male without proclinate orbital seta; 4) abdomen black in ground color; 5) wing vein R1 without setulose; 6) hypandrium without secondary posterior lobe; 7) male with anterobasal $1 / 3$ of flagellomere 1 distinctly swollen; and 8) postgonite very weakly curved dorsally. This species is closely resembles L. hirtipennis, but can be easily distinguished by the above characteristics 5-8.

Redescription of male. Body length 5.9-7.2 mm; wing length 5.55-6.45 mm; Head (Fig. 1C, D) with vertex-head ratio $0.16-0.21$, frons-head ratio $0.16-0.19$, eye ratio $0.50-0.58$, gena-eye ratio $0.27-0.36$, gena-parafacial ratio $1.50-2.25$, flagellomere 1-pedical ratio 1.38-2.25; vertex black with yellowish white pruinosity; occiput black with yellowish white pruinosity; eye densely with fine yellowish white setulae; 1 strong reclinate inner vertical seta; 1 fine outer vertical seta; 1 fine ocellar seta; 1 postocellar seta; 1 paravertical seta; ocellar triangle dark brown with yellowish white pruinosity; orbital plate with yellowish white pruinosity; 1 reclinate orbital seta and 6-8 frontal setae; proclinate orbital seta absent; frontal vitta dark brown and slightly widened anteriorly; parafacial bare; epistome produced between vibrissa in lateral view; antenna predominantly dark brown with apex of pedicel and base of flagellomere 1 reddish brown, pedicel without wart-like process, anterobasal $1 / 3$ of flagellomere 1 distinctly swollen; vibrissa strong with

\footnotetext{
1*황딱부리기생파리 (신칭)
} 

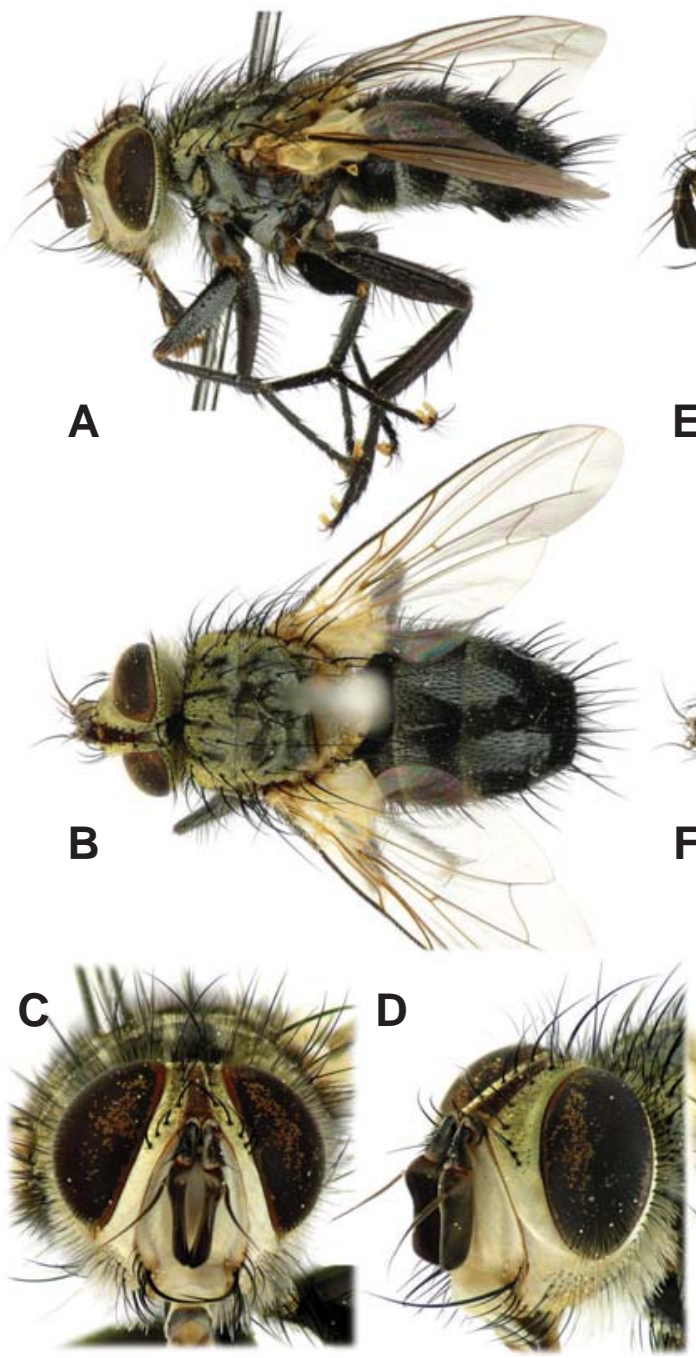

Fig. 1. Linnaemya atriventris. A-D, male; $E-H$, female.

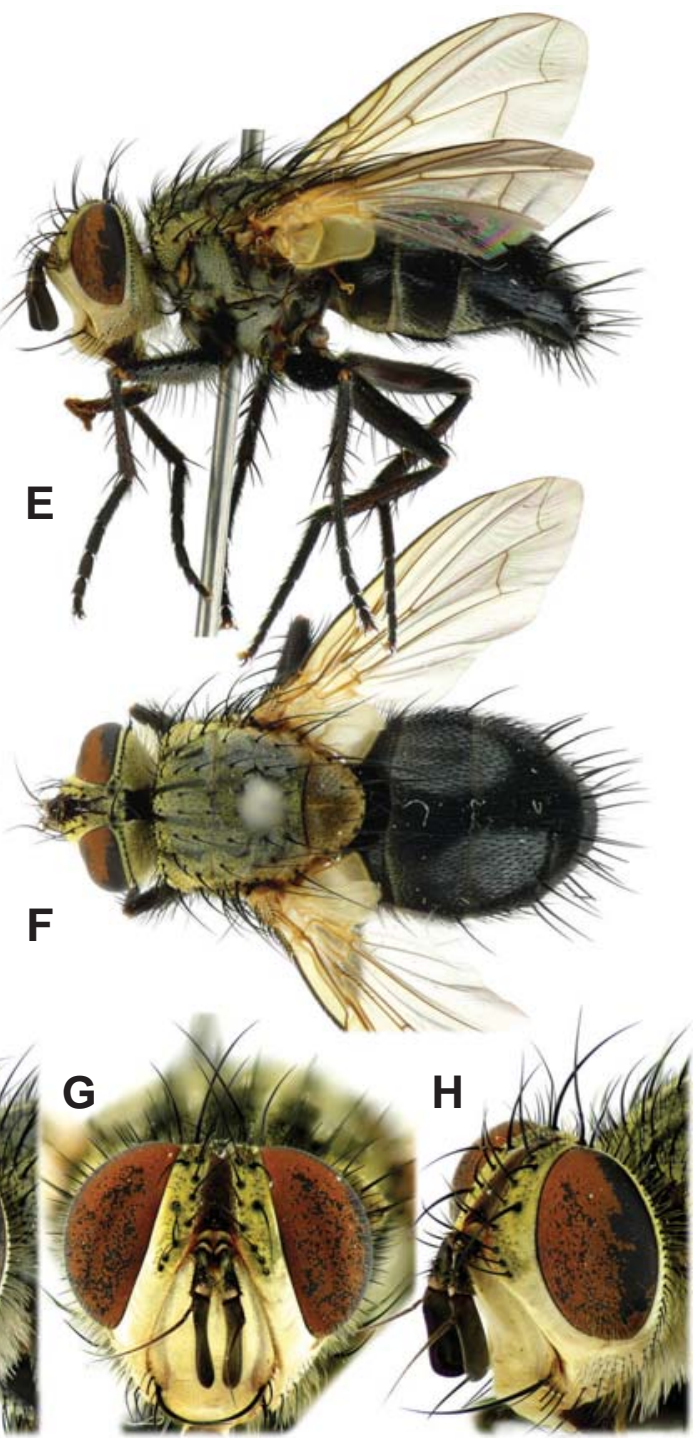

2-3 supravibrissal setae and 7-9 subvibrissal setae; gena with 2-3 strong setulae on anterior portion and dense fine black setulae mixed with yellowish white setulae on lower portion; palpus shorter than 2nd antennal segment. Thorax (Fig. 1A, B) black in ground color with postalar callus and scutellum yellowish brown; scutum densely with fine black setulae, whitish pruinosity with 2 narrow longitudinal dark vittae; prosternum bare; postpronotal lobe with 2 short anterior setae and 3 long posterior setae; 2 posthumeral setae; notopleuron yellowish brown with 2 setae; 1 presutural, 1 pre-alar seta and $3+3$ acrostichal (rarely $4+3$ ), $3+3$ dorsocentral, 3 intra-alar, 2 supra-alar, 2 postalar setae present; pro-episternum black with 2 setae; pro-epimeron with 2 (sometimes 3) setae; katepisternum with 3 setae; anepime- ron densely black setulae with 1 seta not extending beyond middle of lower calyter; anepisternum with vertical row of 6-7 strong setae; katepimeron bare; meron with 6-9 black setulae; scutellum short black setulose, with 1 basal, 1 lateral, 1 pre-apical, 1 apical, 1 discal scutellar seta. Legs (Fig. 1A) predominantly dark brown with black setae; coxae, trochanters and femora with yellowish white and black setulae mixed, but other portions only with black setulae; fore femur with 6-7 dorsal, 8-10 posterodorsal, 9-14 posteroventral setae, posterioly with pale yellowish white pruinosity; fore tibia reddish dark brown with 3 posterior setae; 5th tarsomere with several long brownish black setulae; fore claw and pulvillus about twice as long as 5th tarsomere; mid femur with rows of anteroventral, posteroventral and 1- 
2 anterior setae; mid tibia reddish dark brown with 3-4 anterodorsal, 1-3 posterior setae and 1 ventral seta; hind femur with rows of anterodorsal, anteroventral and posteroventral setae; hind tibia reddish dark brown with 1 dorsal, 5-6 anterodorsal, 3-4 posterodorsal and 3 posteroventral setae. Wing (Fig. 1A, B) hyaline with brownish tinge; veins brown; wing-thorax ratio 1.97-2.16; vein $\mathrm{R}_{4+5}$ ratio 2.15-2.63; vein $\mathrm{M}$ ratio 1.11-1.43; subcostal-costal ratio 0.63-0.67; basicosta yellowish white; tegula dark brown; base of $\mathrm{R}_{4+5}$ with 9-10 black setulose; wing vein $\mathrm{R}_{1}$ without black setulose; extension of $\mathrm{M}$ represented by vein and dark fold, 1.3-1.6x as long as crossvein R-M. Abdomen (Fig. 1A, B) shiny black in ground color; tergite $1+2$ with 1 lateral marginal seta, mid-ventral portion with yellowish white setulae; tergite 3 with 1 median marginal seta and 1-2 lateral marginal setae; tergite 4 with 1 median marginal seta and 1 median discal seta, 1-2 lateral marginal setae; tergite 5 densely covered with strong setae; tergites 3-5 each with shallow whitish pruinosity at anterior $1 / 2-2 / 3$; sternite 1 with yellowish white setulae. Genitalia (Fig. 3A-C) reddish brown to dark brown; sternite 5 deeply notched posteriorly with medial process distinctly longer than lateral process; epandrium dorsally with very strong setae and short setulae; cercus with apex pointed, without median suture; surstylus broad basally and apically narrowed 2 apical spines; pregonite curved ventrally at apex, with several apical setulae; postgonite slightly curved dorsally, apically blunt, slightly shorter than pregonite; epiphallus absent; hypandrium without secondary posterior lobe; distiphallus ventrally produced in lateral view.

Female. (Fig. 1E-H) Similar to males except for the following non-genitalic characters: head with 2 proclinate orbital setae; 1 outer vertical seta about half as long as inner vertical seta, stronger than in male; 1 ocellar seta stronger than in male; orbital plate and frontal plate in anterior view wider than in male; anterobasal 1/3 of flagellomere 1 slightly swollen; arista reddish brown; fore tarsomere wider than in male; fore claw and pulvillus slightly shorter than 5th tarsomere. Lengths and ratios: body 5.7-9.1 mm; wing 5.75$7.45 \mathrm{~mm}$; vertex-head ratio $0.18-0.21$, frons-head ratio $0.12-$ 0.14 , eye ratio $0.47-0.57$, gena-eye ratio $0.27-0.30$, genaparafacial ratio 1.33-1.80, flagellomere 1-pedical ratio $1.70-$ 2.14; wing-thorax ratio 1.97-2.15; vein $\mathrm{R}_{4+5}$ ratio 2.09-2.24; vein $\mathrm{M}$ ratio 1.06-1.24; subcostal-costal ratio 0.62-0.72. Distribution. Korea (South), Russian Far East, Japan (Hokkaido, Honshu, Kyushu), Northern Thailand, Malaysia (Malaya), Indonesia (Java).

Remarks. In Korea, flies of $L$. atriventris can be found from early May to early October on various nectar sources including flowers of Zanthoxylum schinifolium.
$1 *$ Linnaemya hirtipennis Shima (Figs. 2, 3D-F)

Linnaemya hirtipennis Shima, 1986: 80 (type-locality: Japan. Hokkaido, Ashoro, Kiyokawa; Holotype $\sigma^{7}$, BLKU).

Material examined. Holotype $\sigma^{\top}$, JAPAN: Hokkaido, Ashoro, Kiyokawa, 23-VII-1967 (H. Shima) (BLKU). KOREA: [GANGWON-DO] Hoengseong-gun, Dunnae-myeon, Mt. Cheongtaesan, Sapgyo-ri to 1,200 m peak, 17-VI-2003 (D.S. Choi \& H.-W. Byun), 1 중 Pyeongchang-gun, Jinbu-myeon, Pangadari, Mt. Odaesan, 12-VIII-1984 (H.-Y. Han \& K.-E. Ro), 1 우; ditto, 7-IX-1985, 2 지 지 1 우; Wonju-si, Panbu-myeon, Seogok-ri, Mt. Baekunsan, from Yongsu-gol to 1,087 m peak, 7-VI-2003 (H.-Y. Han \& K.-E. Ro), 1 ठ $^{7}$; ditto, 11-VI-2003 (D.-S. Choi \& H.-W. Byun), $1 \sigma^{7}$; ditto, 15-VIII-2003 (H.-W. Byun), 1 ఠ ; ditto, 6-VII-2006 (H.-S. Lee \& S.-M.-R. Hwang), 1 శ; ;GYEONGGI-DO] Gapyeong-gun, Buk-myeon, Mt. Myeongjisan (1,267 m), 19-VI2006 (D.-S. Choi et al.), $1 \sigma^{\nearrow}$; [GYEONGSANGBUK-DO] Mt. Juhulsan, 7-VI-1986 (H.-Y. Han \& K.-E. Ro), $2 \sigma^{\nearrow} \varnothing^{7}$. All the above Korean specimens are deposited in YSUW.

Diagnosis. This species closely resembles $L$. atriventris, but can be differentiated by the following characteristics: 1) dorsal view of scutum with grayish white pruinosity; 2) wing vein $\mathrm{R}_{1}$ setulose dorsally; 3 ) pregonite is thicker than that of L. atriventris; 4) postgonite pointed apically, slightly hooked downward; and 5) hypandrium with secondary posterior lobe.

Redescription of male. Body length 6.0-8.2 mm; wing length 6.35-7.26 mm; Head (Fig. 2C, D) with vertex-head ratio $0.17-0.20$, frons-head ratio $0.15-0.17$, eye ratio $0.48-0.58$, gena-eye ratio $0.26-0.35$, gena-parafacial ratio $1.60-2.20$, flagellomere 1-pedical ratio 1.20-2.00; vertex black with yellowish white pruinosity; occiput black with yellowish white pruinosity; eye densely with yellowish white fine setulae; 1 strong reclinate inner vertical seta; 1 fine outer vertical seta; 1 fine ocellar seta; 1 postocellar seta (rarely absent); 1 paravertical seta; ocellar triangle dark brown with yellowish white pruinosity; orbital plate with yellowish white pruinosity; 1 reclinate orbital seta and 7-8 frontal setae; proclinate orbital seta absent; frontal vitta dark brown and slightly widened anteriorly; parafacial bare; epistome produced between vibrissa in lateral view; antenna predominantly dark brown with apex of pedicel and base of flagellomere 1 reddish brown, pedicel without wart-like process, anterobasal $1 / 3$ of flagellomere 1 slightly swollen; vibrissa strong with 1-3 supravibrissal setae and 8-11 subvibrissal setae; gena with 2-3 strong setulae on anterior portion and dense fine setulae, mixed with yellowish white setulae on lower portion; palpus shorter than 2nd antennal seg-

\footnotetext{
$1 *$ 날개털딱부리기생파리 (신칭)
} 


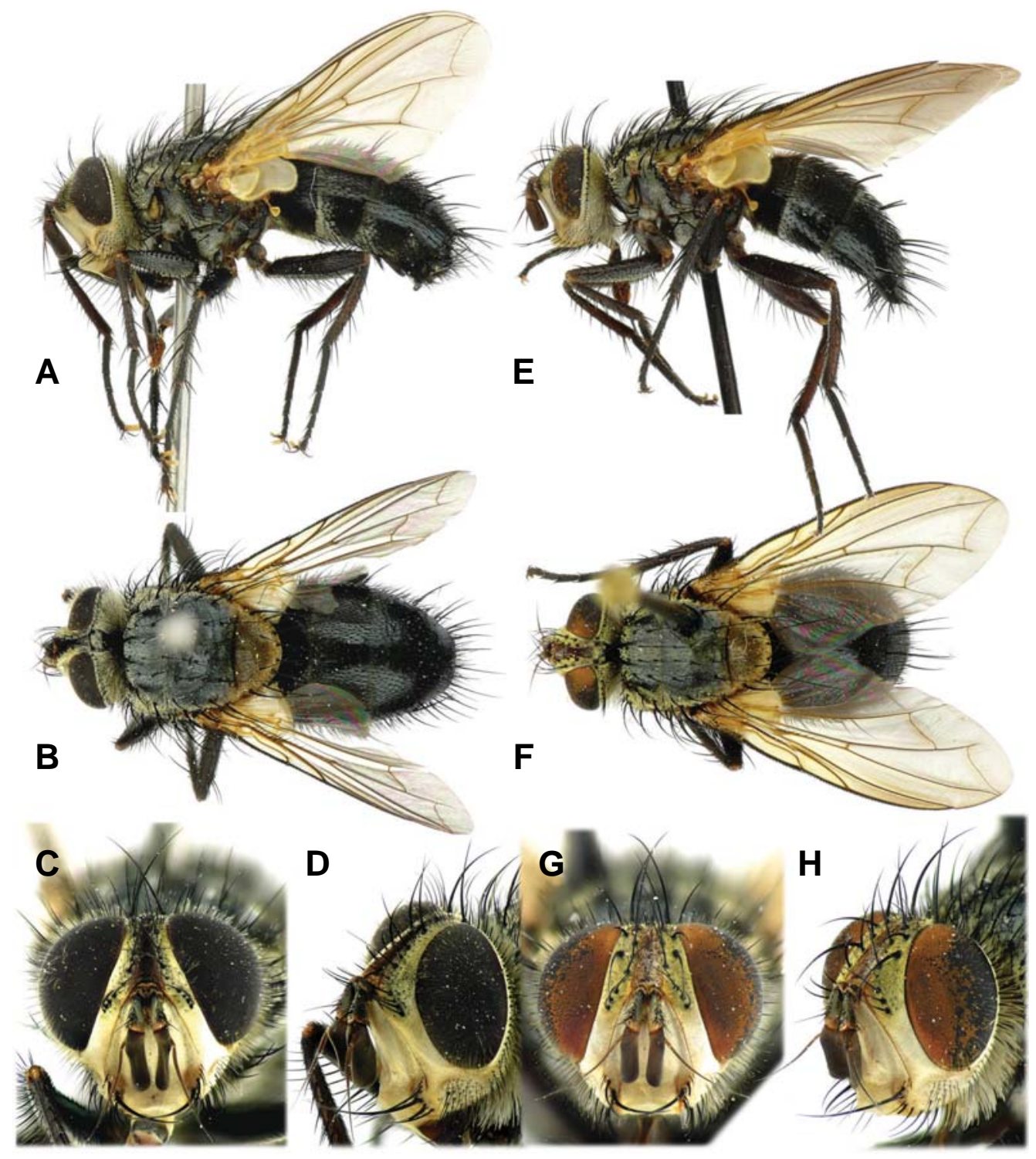

Fig. 2. Linnaemya hirtipennis. A-D, male; E-H, female.

ment. Thorax (Fig. 2A, B) shiny black in ground color with postalar callus and scutellum yellowish brown; scutum densely with fine black setulae, whitish pruinosity with 2 narrow longitudinal dark vittae; prosternum bare; postpronotal lobe with 2 short anterior setae and 3 long posterior setae; 2 posthumeral setae; notopleuron dark brown with 2 setae; 1 presutural, 1 pre-alar seta and $3+3$ acrostichal, $3+3$ dorsocentral, 3 intra-alar, 2 supra-alar, 2 postalar setae present; pro-episternum black with 3 setae; pro-epimeron with 3 setae; katepisternum with 3 setae; anepimeron densely black setulae with 1 seta not extending beyound middle of lower calyter; anepisternum with vertical row of 7-9 strong setae; katepimeron bare; meron with 6-8 black setae arranged; scutellum with short black setulose and 1 basal, 1 lateral, 1 pre-apical, 1 apical, 1 discal scutellar seta. Legs (Fig. 2A) predominantly dark brown with black setae; coxae, trochanters and femora with yellowish white and black setulae mixed, but other portions only with balck setulae; fore femur with 5-8 dorsal, 10-13 posterodorsal, 13 posteroventral setae; fore tibia reddish dark brown with 1-2 strong posterior setae; fore tarsomere dark brown, 5th tarsomere with several long brownish black setulae; fore claw and pulvillus about twice as long as 5th tarsomere; mid femur with rows of anteroventral, posteroventral and 2-4 anterior setae; mid tibia reddish dark brown with 2 anterodorsal, 2 posterior setae and 1 ventral seta; hind femur with 


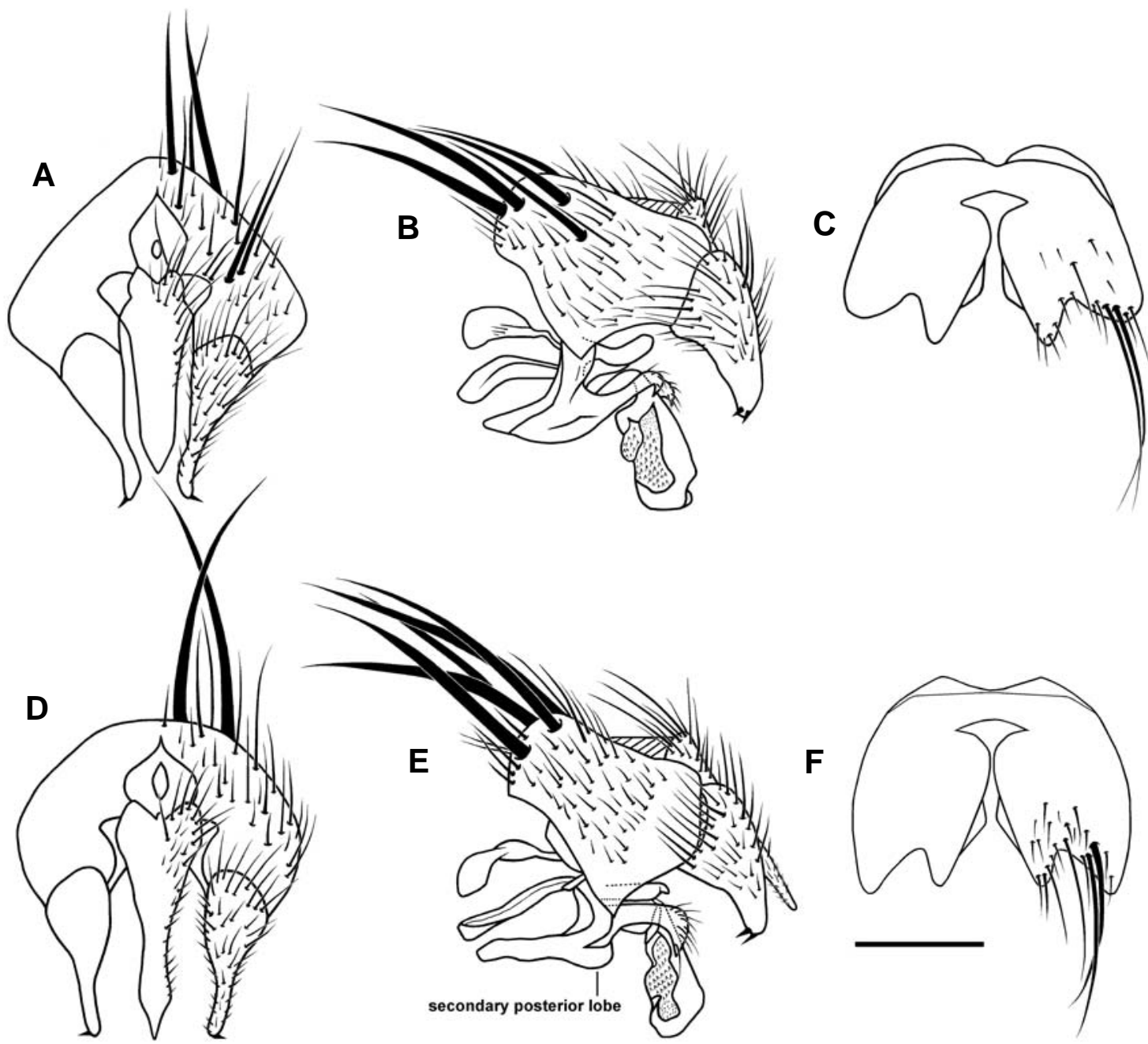

Fig. 3. Male genetalia and sternite 5 of Linnaemya species. A-C, L. atriventris: $A$, male genetalia, caudal view; $B$, male genetalia, lateral view; C, male sternite 5. D-F, L. hirtipennis: D, male genetalia, caudal view; E, male genetalia, lateral view; $F$, male sternite 5. Scale bar $=0.6 \mathrm{~mm}$.

rows of anterodorsal, anteroventral and posteroventral setae; hind tibia reddish dark brown with 1 dorsal, 6-10 anterodorsal, 2-4 posterodorsa setae. Wing (Fig. 2A, B) hyaline with brownish tinged; veins brown; wing-thorax ratio 2.01-2.15; vein $\mathrm{R}_{4+5}$ ratio 2.16-2.50; vein $\mathrm{M}$ ratio 0.93 -1.16; subcostal-costal ratio 0.63-0.69; basicosta yellowish white; tegula dark brown; base of $\mathrm{R}_{4+5}$ with 8-9 setulose; wing vein $\mathrm{R} 1$ with setulose dorsally; extension of $\mathrm{M}$ represented by vein and dark fold slightly shorter than crossvein R-M. Abdomen (Fig. 2A, B) shiny black in ground color; tergite $1+2$ with 1-2 lateral marginal setae, mid-ventral portion with yellowish white setulae; tergite 3 with 1 median marginal seta and 1-2 lateral marginal setae; tergite 4 with 1 median marginal seta and 1 median discal seta, 1-2 lateral marginal setae; tergite 5 densely covered with strong setae; tergite 3-5 each with shallow whitish pruinosity at anterior $1 / 2-2 / 3$; sternite 1 with yellowish white setulae. Genitalia (Fig. 3D-F) reddish brown to dark brown; sternite 5 deeply notched posteriorly with medial process distinctly longer than lateral process; epandrium dorsally with very strong setulae, posteriorly pointed in lateral view; cercus with apex pointed, without median suture; surstylus broad basally and apically narrowed 2 apical spines, in lateral view narrower than $L$. atriventris; pregonite curved ventrally at apex, with several apical setulae, longer and thicker than L. atriventris; postgonite sharply at apex, weakly curved and shorter than pregonite; epiphallus absent; hypandrium with secondary posterior lobe; distiphallus in lateral view with ventral margin slightly produced at middle.

Female. (Fig. 2E-H) Similar to males except for the follow- 
ing non-genitalic characters: head with 2 proclinate orbital setae; 1 outer vertical seta about $1 / 2$ length of inner vertical seta, more developed than in male; 1 ocellar seta more developed than in male; arista reddish brown; fore tarsomere wider than in male; notopleuron yellowish brown; fore claw and pulvillus shorter than 5th tarsomere; wing vein $\mathrm{R}_{1}$ with black setulose as in male. Lengths and ratios: body 8.1-8.2 $\mathrm{mm}$; wing 6.95-7.45 mm; vertex-head ratio 0.20, frons-head ratio $0.11-0.16$, eye ratio $0.60-0.64$, gena-eye ratio 0.24 0.29 , gena-parafacial ratio $1.60-1.67$, flagellomere 1-pedical ratio 1.22-1.63, wing-thorax ratio 2.03-2.08; vein $\mathrm{R}_{4+5}$ ratio 2.12-2.24; vein $\mathrm{M}$ ratio 1.09; subcostal-costal ratio $0.61-$ 0.65 .

Distribution. Korea (South), Japan (Hokkaido).

Remarks. This species is relatively rare and can be occasionally found between June and September in Korea.

\section{ACKNOWLEDGEMENTS}

We are grateful to H. Shima for making the holotype of $L$. hirtipennis available for us when HYH visited Kyushu University in 2002. We also thank N.E. Woodley for the loan of some Linnaemya specimens used in this study. We appreciate K.-E. Ro, D.-S. Choi, H.-W. Byun, H.-S. Lee, O.-Y. Lim, S.-W. Suk, D.-J. Cha, J.-M. Jung and Y.-B. Lee for their assistance to collect Korean Linnaemya specimens. This study was supported by the Korean Ministry of Environment (the Eco-technopia 21 Project and NIBR 074-18001844-326-260-00).

\section{REFERENCES}

Crosskey, R.W., 1973. A conspectus of the Tachinidae (Dip- tera) of Australia, including keys to the supraspecific taxa and taxonomic and host catalogues. Bull. Br. Mus. Nat. Hist. Entomol., Suppl. 21, London, pp. 1-221.

Crosskey, R.W., 1976. A taxonomic conspectus of the Tachinidae (Diptera) of the Oriental Region. Bull. Br. Mus. Nat. Hist. Entomol,. Suppl. 26, London, pp. 1-357.

Crosskey, R.W., 1980. 93. Family Tachinidae. In Crosskey, R.W., ed., Catalogue of the Diptera of the Afrotropical Region. Br. Mus. Nat. Hist. London, pp. 822-882.

Han, H.-Y. and A.L. Norrbom, 2005. A systematic revision of the New World species of Trypeta Meigen (Diptera: Tephritidae). Syst. Entomol., 30: 208-247.

Herting, B. and Á. Dely-Draskovits, 1993. Tachinidae. In Soós, Á. and L. Papp, eds., Catalog of Palaearctic Diptera. Anthomyiidae-Tachinidae, Vol. 13. Hungarian Natural History Museum, Budapest, pp. 118-458.

Herting, B., 1984. Catalogue of Palearctic Tachinidae (Diptera). Stutt. Beitr. Naturk. A (369): 1-228 (in German).

Malloch, J.R., 1935. Exotic Muscaridae (Diptera) XL. Ann. Mag. Nat. Hist., (10)16: 573-597.

McAlpine, J.F., 1981. Morphology and terminology: adult. In McAlpine, J.F., ed., Manual of Nearctic Diptera. Vol. 1. Research Branch, Agriculture Canada, Ottawa, pp. 9-63.

Shima, H., 1986. A systematic study of the genus Linnaemya Robineau-Desvoidy from Japan and the Oriental Region (Diptera: Tachinidae). Sieboldia, 5(1): 1-96.

Wood, D.M., 1987. Tachinidae. In McAlpine, J.F., ed., Manual of Nearctic Diptera. Vol. 2. Research Branch, Agriculture Canada, Ottawa, pp. 1193-1269.

Zimin, L.S., 1954. Species of the genus Linnaemyia RobineauDesvoidy (Diptera, Larvaevoridae) in the fauna of USSR. Trud. Zool. Inst. Akad. Nauk SSSR, 15: 258-282 (in Russian). 